\title{
Isotopically light carbon dioxide in nitrogen rich gases: the gas distribution pattern in the French Massif Central, the Eifel and the western Eger Rift
}

\author{
Falk H. Weinlich \\ Bundesanstalt für Geowissenschaften und Rohstoffe (BGR), Hannover, Germany
}

\begin{abstract}
Based on characteristics of the distribution pattern of the western Eger Rift spring gases, a distribution pattern is presented for the gases of the French Massif Central. The central parts of these areas with ascending magmatic $\mathrm{CO}_{2}$ are characterised by high gas fluxes, high $\mathrm{CO}_{2}$ contents of up to $99.99 \mathrm{vol} \%$ and isotopially heavy $\mathrm{CO}_{2}$. In the peripheries, the decrease of $\delta^{13} \mathrm{C}$ values of $\mathrm{CO}_{2}$ and $\mathrm{CO}_{2}$ contents in the gas phase is compensated by a rise in $\mathrm{N}_{2}$ contents. It can be demonstrated that gas fractionation in contrary to mixtures with isotopically light biogenic or crustal $\mathrm{CO}_{2}$ controls the distribution pattern of gas composition and isotopic composition of $\mathrm{CO}_{2}$ in these spring gases. Dissolution of $\mathrm{CO}_{2}$ results in formation of $\mathrm{HCO}_{3}^{-}$causing isotope fractionation of $\mathrm{CO}_{2}$ and an enrichment of $\mathrm{N}_{2}$ in the gas phase. With multiple equilibrations, values of about $-17 \% \circ$ or lower are obtained. The scale of gas alteration depends on the gas flux and the gas-water ratios respectively and can result in $\mathrm{N}_{2}$-rich gases. Essential for the interpretation are gas flux measurements with mass balances derived for most of the springs. Without such mass balances it is not possible to discriminate between mixture and fractionation. The processes of isotopic and chemical solubility fractionations evidently control the gas distribution pattern in other regions as well.
\end{abstract}

Key words Eger Rift - French Massif Central Eifel - carbon dioxide - gas fractionation - isotope composition

\section{Introduction}

In areas with both low $\mathrm{CO}_{2}$ abundance and contents in the gas phase as for example in complexes of crystalline basement or in areas with younger volcanic activity, one frequently encounters $\mathrm{CO}_{2}$ with isotopic compositions of $\delta^{13} \mathrm{C}$ values lesser than $-10 \%$. In many cases,

Mailing address: Dr. Falk H. Weinlich, Referat Gasund Isotopengeochemie, Bundesanstalt für Geowissenschaften und Rohstoffe (BGR), Stilleweg 2, 30655 Hannover, Germany; e-mail: falkweinlich@gmx.de such values are interpreted as biogenic/organic $\mathrm{CO}_{2}$ or mixtures between magmatic and biogenic $\mathrm{CO}_{2}$ or respectively mantle and crustal end members (e.g., Griesshaber et al., 1992). It appears that $\mathrm{CO}_{2}$ gases with low $\delta^{13} \mathrm{C}$ values occurring in the margin areas of regions with ascending magmatic $\mathrm{CO}_{2}$ as for example in mineral springs of the western Eger Rift, the Eifel or the French Massif Central (Batard et al., 1982) confirm this interpretation.

However, due to the high solubility of $\mathrm{CO}_{2}$ in water and the $\mathrm{HCO}_{3}$ formation, fractionations of the $\mathrm{CO}_{2}$-rich gases take place (e.g., Batard et al., 1982; Capasso et al., 1997; D’Alesandro et al., 1997; Chiodini et al., 1999; Weinlich et al., 1999).

Commonly, the isotopic data are compared and calculated with a single equilibration. However, in the peripheral areas of regions with magmatic $\mathrm{CO}_{2}$ marked by longer migration 
pathways, it can be assumed that gases migrate in different water systems, for example along various faults where dissolution of $\mathrm{CO}_{2}$ and fractionation with concomitantly formed $\mathrm{HCO}_{3}^{-}$ can take place several times. This results in a comprehensive gas fractionation concerning both gas composition and isotopic composition of $\mathrm{CO}_{2}$ and can yield $\mathrm{N}_{2}$-rich gases.

\section{Gas distribution pattern in European areas with magmatic $\mathrm{CO}_{2}$}

\subsection{Western Eger Rift (Czech Republic)}

In the western Eger Rift the main release of magmatic $\mathrm{CO}_{2}$-rich gases is bound to gas release-centres in the Cheb Basin and Karlovy Vary north and Mariánské Lázně south of the main structures of Eger Rift (Weinlich et al., 1998). These structures of the Krušné hory (Erzgebirge) main fault together with the central fault both dipping to south and the Litomerrice deep fault dipping to north form a Y-structure. This Y-structure splits the gas flux and forms a shielded gas free zone within the Eger Rift.

The gases of the mofettes and springs in these areas with the highest gas fluxes are characterised by high $\mathrm{CO}_{2}$ contents of up to $99.99 \mathrm{vol} \%$ and $\delta^{13} \mathrm{C}$ values of -3.9 up to $-1.9 \%$ (fig. 1 ). In some mofettes and springs the gas flux reach values up to $28 \mathrm{~m}^{3} / \mathrm{h}$ in Bublák and $35 \mathrm{~m}^{3} / \mathrm{h}$ in Soos (Cheb Basin) or about $100 \mathrm{~m}^{3} / \mathrm{h}$ in the Mariiny mofette in Mariánské Lázně. The magmatic nature of these gases is indicated, besides these $\delta^{13} \mathrm{C}$ values, by high proportions of mantle-derived helium with $R / R_{a}$ values up to 6 (Weinlich et al., 1999).

With increasing distances from these gas release-centres the gas flux falls and related to it the $\mathrm{CO}_{2}$ becomes isotopically lighter whereas the $\mathrm{CO}_{2}$ contents decrease and are compensated by a rise of the $\mathrm{N}_{2}$ and $\mathrm{He}$ contents. To the east and south of Konstantinovy Lázně the $\mathrm{CO}_{2}$ contents drop linked with gas fluxes of lower than a half $1 / \mathrm{h}$ up to values of 87 and $67 \mathrm{vol} \%$, respectively. To the north of the Eger Rift nitrogen contents of 98 vol\% are attained apart from $0.7 \mathrm{vol} \% \mathrm{CO}_{2}$ as in the Schönbrunn fluorite mine or in other spring gases in the Erzgebirge (Weinlich, 1989). Linked with the decrease of the $\mathrm{CO}_{2}$ contents in the gas phase is a decrease of the $\delta^{13} \mathrm{C}$ values of $\mathrm{CO}_{2}$. South of the Eger Rift, the $\delta^{13} \mathrm{C}$ values fall to $-7.4 \%$ in the Konstantinovy Lázně area and to $-8.8 \%$ in $\mathrm{Ba}-$ varia, respectively. In the same way, the $\delta^{13} \mathrm{C}$ values of $\mathrm{CO}_{2}$ decrease north of the Eger Rift down to $-6.0 \%$ in Bad Elster and in the $\mathrm{N}_{2}$-rich gases of Schönbrunn down to a value of $-17.4 \%$.

The gases in the mofettes and mineral springs in the western Eger Rift migrate upwards along faults in the area with exposed metamorphic rocks of Variscian in the north and of Moldanubian consolidated basement in the south or with exposed Variscan granite intrusions. The metamorphic rocks in this area have very low potential if any for a $\mathrm{CO}_{2}$ release because all organic carbon is fixed thermodynamically as very stable graphite. In the course of the Variscan, metamorphism mobilised and displaced organic carbon with $\delta^{13} \mathrm{C}$ values of $-14 \%$ is present in the form of $\mathrm{CO}_{2}$ gases among others in the fluid inclusions of granitic quartz in Schönbrunn. With a decrepitation temperature of $800^{\circ} \mathrm{C}$ (Weise et al., 2001), the release of $\mathrm{CO}_{2}$ gases by mineral waters is today hardly possible.

\subsection{Eifel (Lower Rhine Graben, Germany)}

$\mathrm{CO}_{2}$-rich gases linked with Quaternary volcanic activities occur also in the Eifel. Griesshaber et al. (1992) report isotopic compositions of $\mathrm{CO}_{2}$ ranging from $-7.8 \%$ up to $-3 \%$. The lighter isotopic values are explained with the aid of lower $R / R_{a}$ values due to mixing of magmatic and biogenic $\mathrm{CO}_{2}$.

May (2002) describes the occurrence of $\mathrm{CO}_{2}$-rich gases linked with higher gas fluxes within the central West Eifel and the decrease of $\mathrm{CO}_{2}$ contents in its margin areas (fig. 2). So gases with up to $98.3 \mathrm{vol} \% \mathrm{CO}_{2}$ predominate for $e . g$., in Wallenborn in the central part of the West Eifel and with up to 99 vol\% in Laach lake in the East Eifel. The $\delta^{13} \mathrm{C}$ values of $\mathrm{CO}_{2}$ in the West Eifel range from -5.7 up to $-2.0 \%$ (Hubberten, 2004, pers. comm.) and in the central parts of the East Eifel from -5.1 up to $-3 \%$ o (Griesshaber et al., 1992).

In contrast, away from these areas with high gas fluxes, gases with higher $\mathrm{N}_{2}$ contents occur 

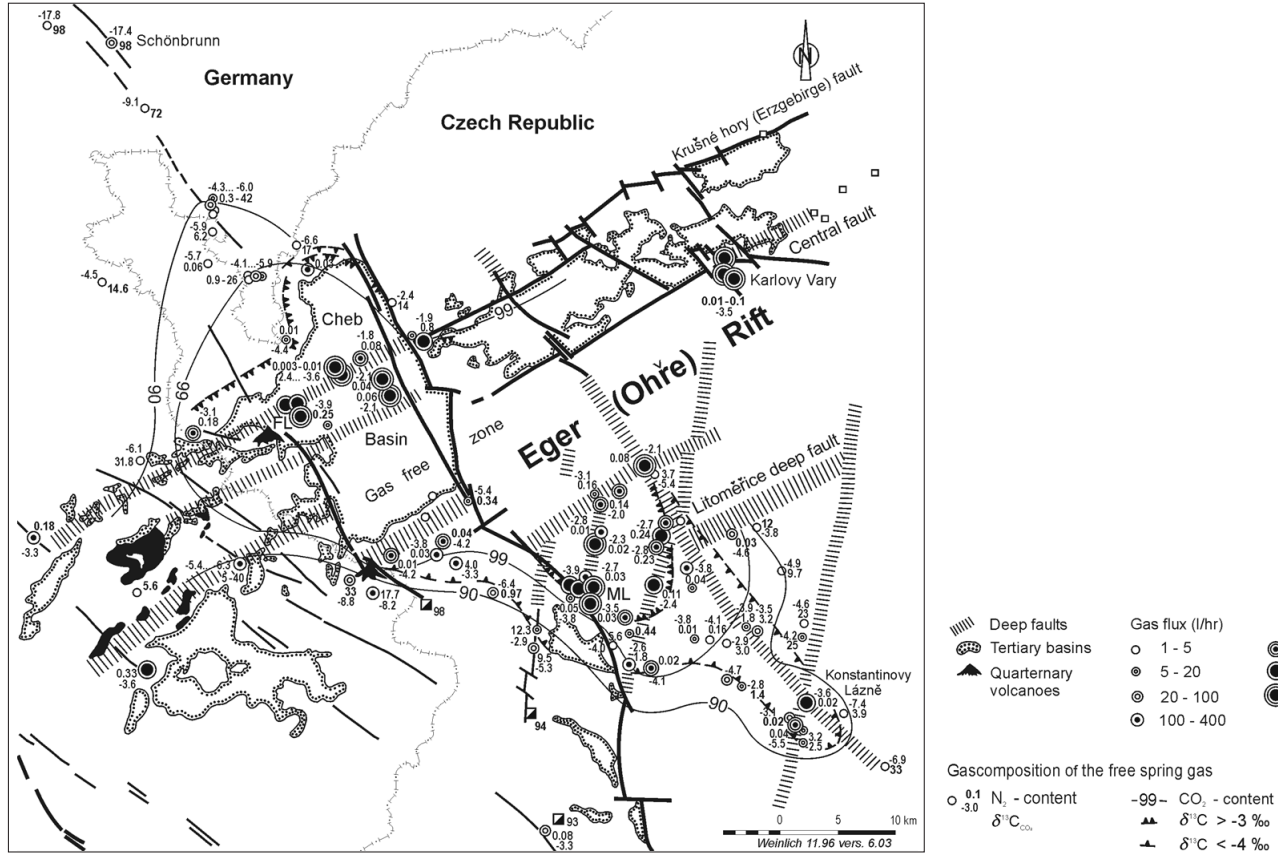

Fig. 1. Distribution pattern of gas flux (free gas), gas composition (air-free) and $\delta^{13} \mathrm{C}_{\mathrm{CO}_{2}}$ values of gases in mineral springs and mofettes in the western Eger Rift, Czech Republic (data taken from Weinlich et al., 1998, 1999, 2003). Legend: ML - Mariánské Lázně; FL - Františkovy Lázně; half-filled squares - uranium mines with gas blowouts.

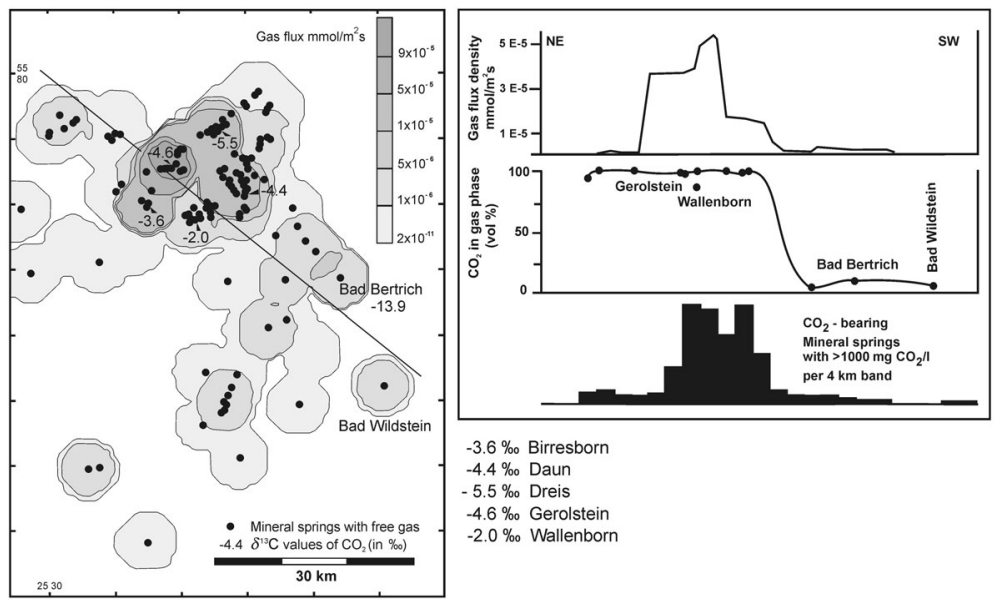

Fig. 2. Gas flux distribution (moving average for circles with $8.6 \mathrm{~km}$ diameter), isotope composition of $\mathrm{CO}_{2}$ and schematic profile of $\mathrm{CO}_{2}$ flux, spring density and gas composition across the West Eifel, after May (2002). Carbon isotope data from Griesshaber et al. (1992) and Hubberten (2004, pers. comm.). The Brubble spring of Wallenborn (wallen - seethe, born - spring) is a geyser-like spring with gas release of $11.3 \mathrm{~m}^{3}$ per eruption period (May, 2002) the spring with the highest gas flux and the highest $\delta^{13} \mathrm{C}_{\mathrm{CO}_{2}}$ value $(-2.0 \%$ ) in the West Eifel. 
in the spring gases of Aachen (27 vol\% $\mathrm{N}_{2}, 72$ vol\% $\mathrm{CO}_{2}$ ) located to the northwest of Eifel or in the southeast at Bad Bertrich $\left(90 \mathrm{vol} \% \mathrm{~N}_{2}, 6.2\right.$ vol\% $\left.\mathrm{CO}_{2}\right)$ and Bad Wildstein $\left(98.5\right.$ vol\% $\mathrm{N}_{2}$, 0.13 vol\% $\mathrm{CO}_{2}$ ) (May, 2002). Congruent with the alteration of gas composition Beyer (1995) reports $\delta^{13} \mathrm{C}$ values of $\mathrm{CO}_{2}$ ranging from -10.2 up to $-6.3 \%$ o for the thermal springs of Aachen.
In the $\mathrm{N}_{2}$-rich gas of Bad Bertrich, $\delta^{13} \mathrm{C}$ value of $\mathrm{CO}_{2}$ amounts to $-13.9 \%$ (own analysis). The $\delta^{13} \mathrm{C}$ values of $\mathrm{CO}_{2}$ in these marginal springs are significantly lower than in the central parts.

The gases ascent along faults in an area with exposed Devonian sediments and are occur mainly in the areas of the Maar-type Quaternary volcanism in the East and West Eifel.

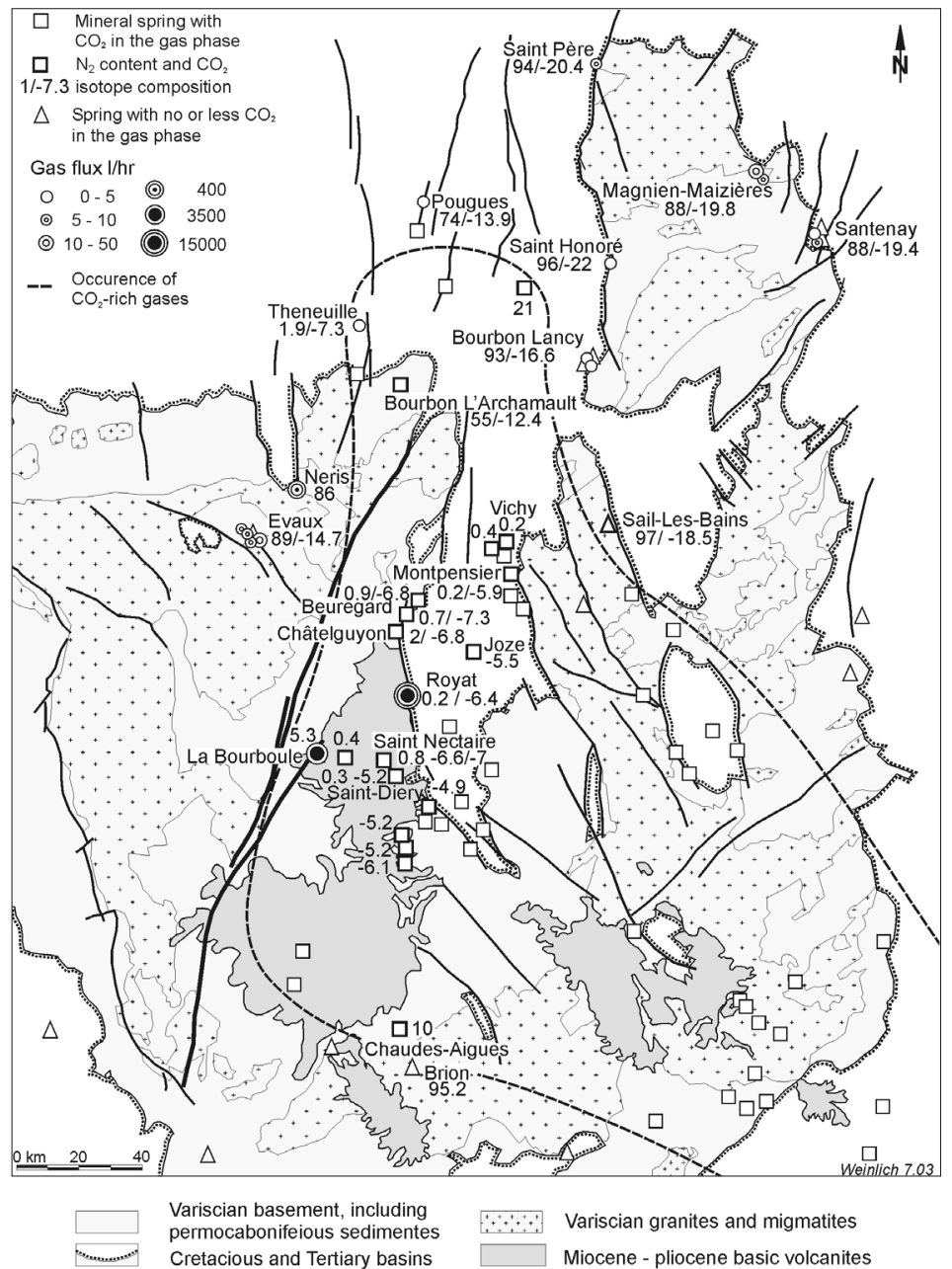

Fig. 3. Distribution of gas flux (free gas), gas composition and $\delta^{13} \mathrm{C}_{\mathrm{CO}_{2}}$ values of the gases of the mineral springs of the French Massif Central. Compiled after data from Moureu and Lepape (1912), Moureu (1923), Baubron et al. (1979), Schoeller and Schoeller (1979), Batard et al. (1982) and Matthews et al. (1987). Based on the hydrologic map (Risler et al., 1973) and tectonic map (Autran et al., 1980). 


\subsection{French Massif Central}

In the French Massif Central $\mathrm{CO}_{2}$ occurs with $\delta^{13} \mathrm{C}$ values ranging from $-23 \%$ up to $-4 \%$.

The $\mathrm{CO}_{2}$-rich gases of Vichy, Royat or Mont Dore and Cezallier ( $>99$ vol\% $\mathrm{CO}_{2}$ ) are bound to the area of Limagne depression or its direct vicinity. Matthews et al. (1987) proved the mantle-derived nature of these gases with $R / R_{a}$ of up to 5.5. Gas flux measurements (Moureu and Lepape, 1912; Batard et al., 1982) carried out on these spring gases in the above region also show that the $\mathrm{CO}_{2}$-rich gases are linked with high gas fluxes.

According to the gas composition and isotope data by Moureu (1923), Schoeller and Schoeller (1979), Baubron et al. (1979), Batard et al. (1982) and Matthews et al. (1987) a similar distribution pattern also prevails there. In the central part of the Massif Central isotopically heavy $\mathrm{CO}_{2}$ with $\delta^{13} \mathrm{C}$ values of -7 up to $-5 \%$ occurs linked exclusively with $\mathrm{CO}_{2}$-rich gases whereas isotopically lighter $\mathrm{CO}_{2}$ with $\delta^{13} \mathrm{C}$ values ranging from -23 up to $-12 \%$ is linked with $\mathrm{N}_{2}$-rich gases of Evaux (89-93 vol\%), Sail-Les-Bains (97.2 vol\%) Maizières (88.2 vol\%) or Santenay (86-88 vol\% $\mathrm{N}_{2}$ ) in the margin areas (fig. 3). The latter values are in the range of «typical» biogenic $\mathrm{CO}_{2}$.

Apart from the Limagne depression filled with Oligocene - Quaternary sediments where the spring gases migrate upward along marginal faults and the volcanic complex of Mont Dore these spring gases migrate upward along faults in areas with exposed Variscian metamorphic rocks or granites.

\section{3. $\mathrm{CO}_{2}$ fractionation}

\subsection{The gases in the western Eger Rift}

In contrast to other gases, $\mathrm{CO}_{2}$ is very vulnerable to fractionation processes. Firstly, due to its good solubility in water compared to $\mathrm{N}_{2}$, HC's and rare gases, the gas composition can be altered solely by solubility fractionations. This results in enrichment of the inert gases as observed by an aureole of $\mathrm{N}_{2}$-richer gases in the surroundings of all regions with $\mathrm{CO}_{2}$-rich magmatic gases in Europe. Figure 4 demonstrates that with an ongoing solution of $\mathrm{CO}_{2}$ resulting

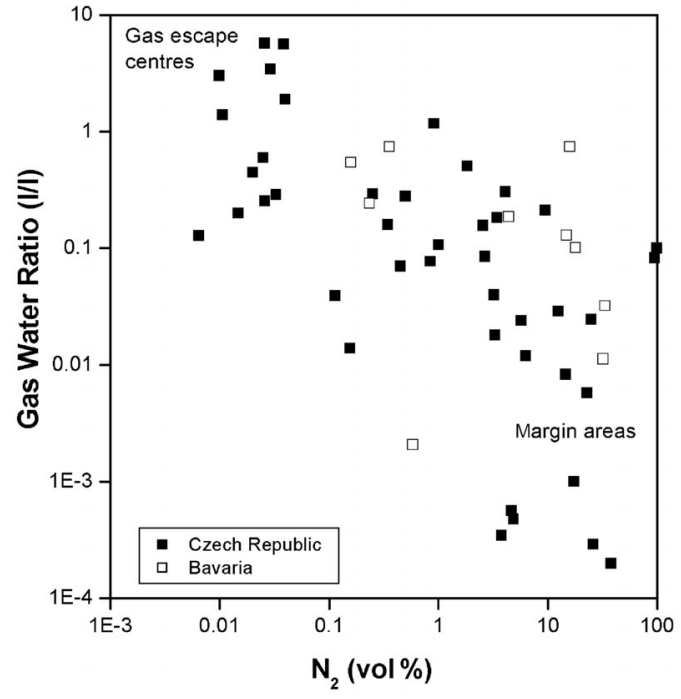

Fig. 4. Rise of $\mathrm{N}_{2}$ (air-free) in gases with decreasing free gas-water ratio due to increased gas fractionation, i.e. selective $\mathrm{CO}_{2}$ solution in water. The unavoidable scattering in the data is due to varying air proportions in the gases by different partial pressures influencing the bubble point pressure of the gas-water systems (data from Weinlich et al., 1998, 2003).

in a decrease of the gas/water ratios the gases in the western Eger Rift are enriched in $\mathrm{N}_{2}$ in the gas phase (Weinlich et al., 1998).

Secondly, linked with the solution of $\mathrm{CO}_{2}$ are decreasing $\mathrm{pH}$ values of these waters. This results in leaching of cations from the adjacent rocks and formation of $\mathrm{HCO}_{3}^{-}$ions. Between the newly formed $\mathrm{HCO}_{3}^{-}$and $\mathrm{CO}_{2}$ in the gas phase exists an isotope fractionation of about $10 \%$ (at $10^{\circ} \mathrm{C}$ ) (Wendt, 1968).

With ongoing $\mathrm{HCO}_{3}^{-}$formation, the remaining $\mathrm{CO}_{2}$ in the gas phase becomes isotopically lighter. Consequently, the decreasing gas flux correlates with decreasing $\delta^{13} \mathrm{C}$ value of $\mathrm{CO}_{2}$ in the gas phase as demonstrated in the distribution pattern for the Eger Rift gases.

However, isotopically lighter $\mathrm{CO}_{2}$ can be also a result of mixing of biogenic and magmatic $\mathrm{CO}_{2}$. The key for discrimination between mixing or fractionation is the compilation of complete mass balances of $\mathrm{CO}_{2}$ for each mineral spring with a 
free gas phase consisting of gas flux, isotopic and chemical gas composition, contents of $\mathrm{HCO}_{3}^{-}$and dissolved $\mathrm{CO}_{2}$ contents and water discharge.

According to Wendt (1968) the isotope balance for $\mathrm{CO}_{2}$ in the free gas phase can be de- scribed by the following equation:

$$
\begin{aligned}
& \delta^{13} \mathrm{C}_{\text {gas }}=\delta^{13} \mathrm{C}_{\text {total }}-\left(m_{\text {diss }} / m_{\text {total }}\right) \varepsilon_{w-\text { gas }}+ \\
& -\left(m_{\mathrm{HCO}_{3}} / m_{\text {total }}\right) \varepsilon_{\mathrm{HCO}_{3} \text { gas }}
\end{aligned}
$$

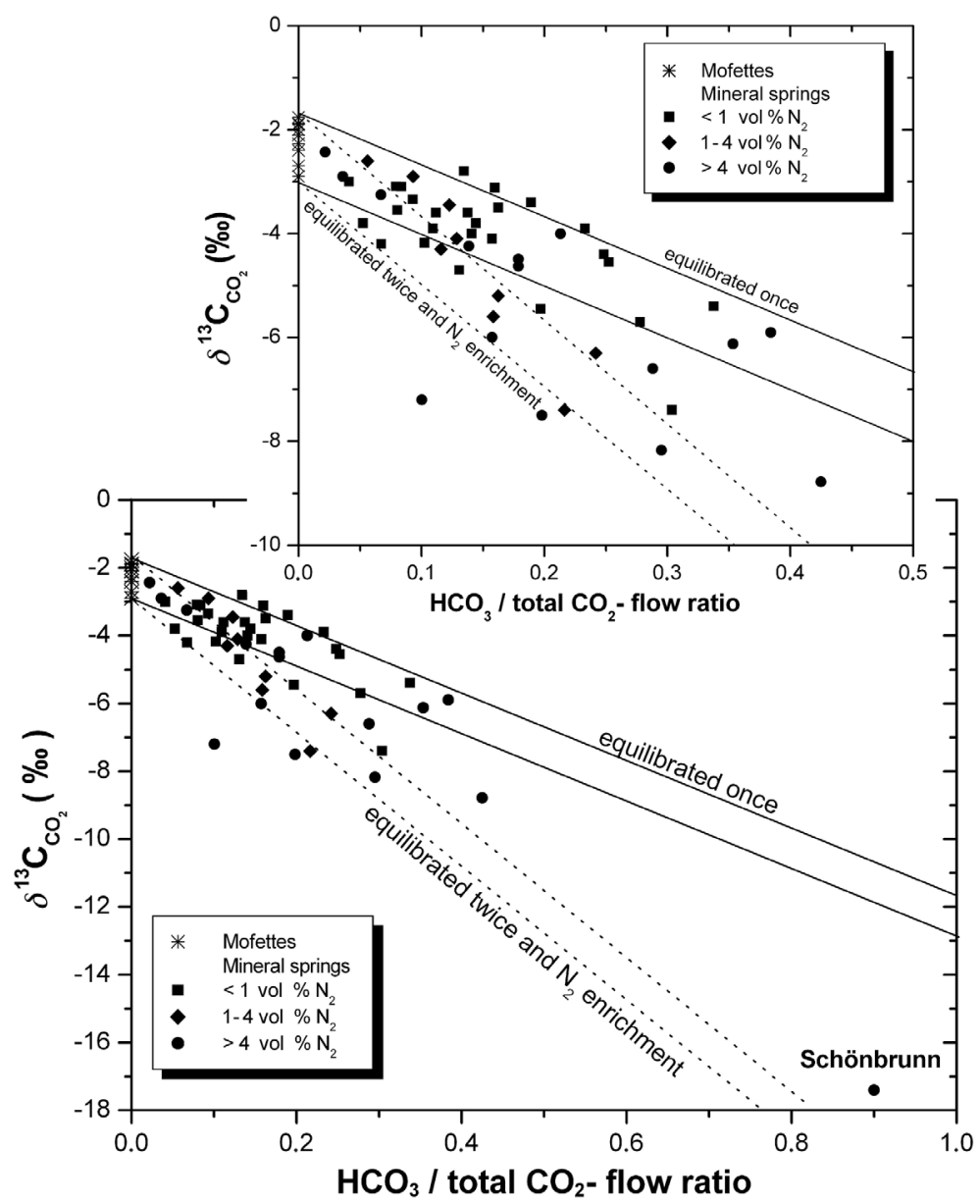

Fig. 5. Dependence of $\delta^{13} \mathrm{C}_{\mathrm{CO}_{2}}$ values in free gas phase from the ratio of $\mathrm{HCO}_{3}^{-}$transport $\left(m \mathrm{HCO}_{3}\right)$ in water to total $\mathrm{CO}_{2}$ flux in mineral springs and mofettes in the western Eger Rift with complete mass balances, according to the isotope balance formula (see text) (data of $\mathrm{HCO}_{3}^{-}$, dissolved $\mathrm{CO}_{2}$ and water discharge are taken from Kolářová and Myslil, 1979 and Weinlich et al., 1999, 2003). Lines starting from the scattering range of the dry gas vents (on the $y$ axis) in the mofettes wrap the field of theoretical fractionation according to the fractionation factor $\varepsilon \mathrm{HCO}_{3 \text {-gas }}$ at $10^{\circ} \mathrm{C}$. Between these lines, the $\delta^{13} \mathrm{C}$ values for the free gas are exclusively a result of fractionation by the means of formed $\mathrm{HCO}_{3}^{-}$during a single equilibration, without the necessity to assume an additional biogenic carbon. The $\delta^{13} \mathrm{C}$ values below the lines can be explained by twice equilibration. This results in an increase of $\mathrm{N}_{2}$. Multiple equilibrations with solely dissolved $\mathrm{CO}_{2}$ and single equilibration with $\mathrm{HCO}_{3}^{-}$result in occurrence of $\mathrm{N}_{2}$-richer gases, which fall in between the fractionation lines. 
Table I. Measured and calculated $\delta^{13} \mathrm{C}$ values of $\mathrm{CO}_{2}$ for springs in the vicinity of mofettes in North Bohemia demonstrate that the differences between mofettes and springs are solely caused by $\mathrm{HCO}_{3}^{-1}$ fractionation. For the $\delta^{13} \mathrm{C}_{\text {primary (total) }}$ - value the isotope signature of the neighbouring mofettes, the $\mathrm{HCO}_{3}$ as well as dissolved $\mathrm{CO}_{2}$ and the water discharge of the respective spring were used according to isotope balance formula (data from Weinlich et al., 1998, 1999).

\begin{tabular}{|c|c|c|c|c|c|c|c|c|c|}
\hline Locality, spring & $\begin{array}{l}\mathrm{CO}_{2} \\
\mathrm{vol} \%\end{array}$ & $\begin{array}{c}\text { Gas flux } \\
1 / h\end{array}$ & $\begin{array}{c}\text { Water } \\
\text { discharge } \\
1 / h\end{array}$ & $\begin{array}{c}\text { Free gas } \\
\mathrm{mol} / \mathrm{h}\end{array}$ & $\begin{array}{c}\mathrm{CO}_{2}-1 \\
\text { Dissolved } \\
\mathrm{mol} / \mathrm{h}\end{array}$ & $\begin{array}{l}\text { flux } \\
\mathrm{HCO}_{3}^{-} \\
\mathrm{mol} / \mathrm{h}\end{array}$ & $\begin{array}{c}\text { Total } \\
\mathrm{mol} / \mathrm{h}\end{array}$ & $\begin{array}{c}\delta^{13} \mathrm{C} \\
\text { Measured } \\
\% o\end{array}$ & $\begin{array}{c}\mathrm{CO}_{2} \\
\text { Calculated } \\
\% 0\end{array}$ \\
\hline \multicolumn{10}{|l|}{ Cheb Basin } \\
\hline Soos, mofettes & 99.946 & 21100 & 0 & 941.46 & 0 & 0 & 941.46 & -2.9 & \\
\hline $\begin{array}{l}\text { Soos, Cisařsý } \\
\text { Františkovy Lázně }\end{array}$ & 99.941 & 7600 & 2520 & 339.08 & 143.18 & 60.7 & 542.96 & -3.6 & -3.64 \\
\hline Kostelní spring & 99.017 & 2500 & 8600 & 110.51 & 418.08 & 84.31 & 612.90 & -3.6 & -3.34 \\
\hline \multicolumn{10}{|l|}{ Mariánské Lázně } \\
\hline Smrad'och mofettes & 99.923 & 5200 & 0 & 231.96 & 0 & 0 & 231.96 & -2.27 & \\
\hline Farská spring & 99.610 & 149 & 1166 & 6.63 & 67.73 & 11.55 & 85.91 & -2.8 & -2.55 \\
\hline Mariiny mofette & 99.990 & 87000 & 0 & 3883.54 & 0 & 0 & 3883.54 & -2.7 & \\
\hline Ferdinand spring II & 99.969 & 8240 & 1440 & 367.74 & 70.85 & 71.86 & 510.45 & -4.0 & -3.88 \\
\hline Křížový spring III & 99.625 & 135.6 & 72 & 6.03 & 4.74 & 3.27 & 14.04 & -3.9 & -4.52 \\
\hline Martinov & 99.280 & 4 & 90 & 0.18 & 5.28 & 1.06 & 6.52 & -3.5 & -3.22 \\
\hline Chotěnov & 85.570 & 4.1 & 171.1 & 0.16 & 8.54 & 2.35 & 11.05 & -4.0 & -3.75 \\
\hline Dolní Kramolín & 99.370 & 164 & 324 & 7.28 & 19.29 & 1.58 & 28.15 & -2.6 & -2.35 \\
\hline
\end{tabular}

where $m$ is the amount of $\mathrm{CO}_{2}$ and $\varepsilon$ the fractionation factors of $-1.3 \%$ or $\varepsilon_{\text {diss-gas }}$ and $9.6 \%$ for $\varepsilon \mathrm{HCO}_{3}$-gas at $10^{\circ} \mathrm{C}$ (Wendt, 1968 ; Mook et al., 1974; Zhang et al., 1995).

In case of the mofettes the water discharge is 0 , i.e. the ratios $m_{\mathrm{diss}} / m_{\mathrm{total}}$ and $m_{\mathrm{HCO}} / m_{\mathrm{total}}$ are 0 . Consequently, the measured $\delta^{13} \mathrm{C}$ value of the free gas phase is identical to the total, i.e. the primary isotopic composition of magmatic $\mathrm{CO}_{2}$ in this area. Therefore $m_{\mathrm{HCO}_{3}} / m_{\text {total }}$ ratios near 0 can be used to identify the primary isotopic composition.

In the case of mineral springs with a continuous transport of leached cations, mainly $\mathrm{Ca}^{++}$and $\mathrm{Mg}^{++}$, isotopic fractionation occurs with contemporaneously formed $\mathrm{HCO}_{3}^{-}$whereas remaining $\mathrm{CO}_{2}$ in the gas phase becomes isotopically lighter and $\mathrm{CO}_{2}$ contents can decrease. Figure 5 exhibits this dependency of the $\delta^{13} \mathrm{C}$ value of $\mathrm{CO}_{2}$ in the gas phase from the $m_{\mathrm{HCO}_{3}} / m_{\text {total }}$ ratios in the springs. In cases of spring gases in the close vicinity of mofettes it can be demonstrated that the differences in the isotopic composition are solely caused by $\mathrm{HCO}_{3}^{-}$fractionation (table I).

The spring gases, which are further away from the main gas release-centres, can be transported within more than one fault system and thus in different waters. Therefore, the equilibration between $\mathrm{CO}_{2}$ in the gas phase and $\mathrm{HCO}_{3}^{-}$can occur several times and the calculated $\delta^{13} \mathrm{C}_{\mathrm{CO}_{2}}$-values are consequently higher than expected in a single equilibration.

Changes in isotopic composition can also be explained by mixing with lighter biogenic $\mathrm{CO}_{2}$. However, the common change in isotopic and chemical composition (fig. 6) points to fractionation processes caused by multiple equilibrations as increasing nitrogen contents are not linked with biogenic $\mathrm{CO}_{2}$ admixtures. In the gases of the western Eger Rift a correlation between $\mathrm{N}_{2}$ and $\mathrm{He}$ contents can be observed (fig. 7) which indicates one source and 


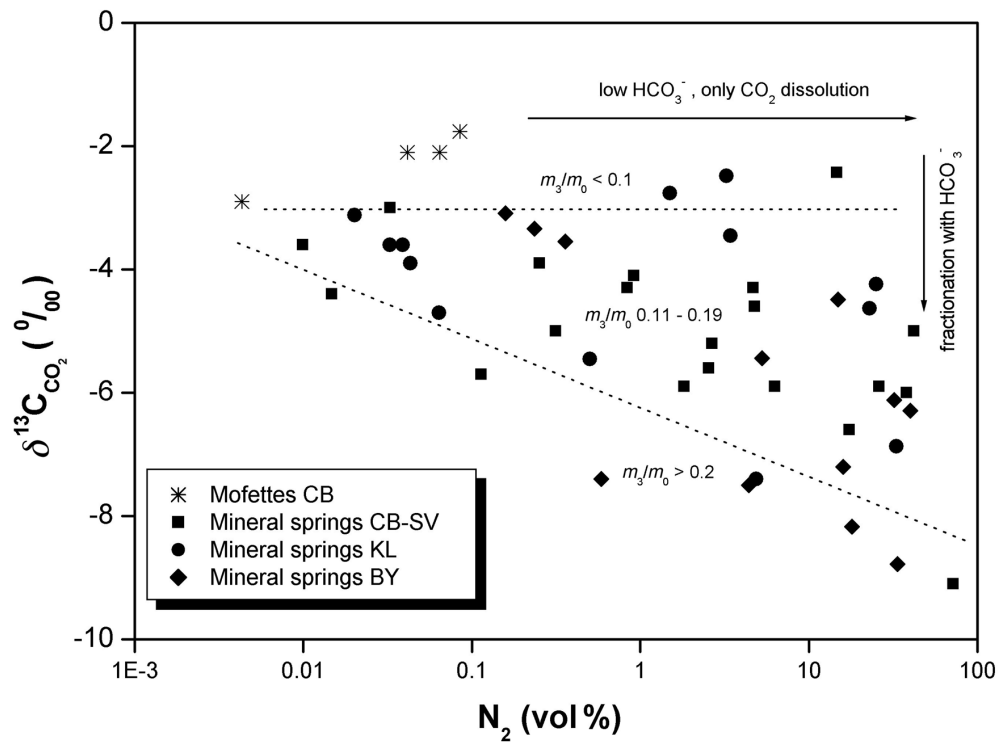

Fig. 6. Plot of $\mathrm{N}_{2}$ content versus $\delta^{13} \mathrm{C}$ values displays the common variations in gas and isotope composition of gases from the Eger Rift area, e.g., from the Cheb Basin/South Vogtland area (CB-SV), Konstantinovy Lázně area (KL) and Bavaria (BY). These variations are caused by fractionation $\left(\mathrm{CO}_{2}\right.$ solution and $\mathrm{HCO}_{3}^{-}$formation). In the case of waters with low TDS contents and without $\mathrm{HCO}_{3}^{-}$formation, the fractionation can only take place with dissolved $\mathrm{CO}_{2}$ and the isotopic heavy $\mathrm{CO}_{2}$ remains therefore in the gas phase.

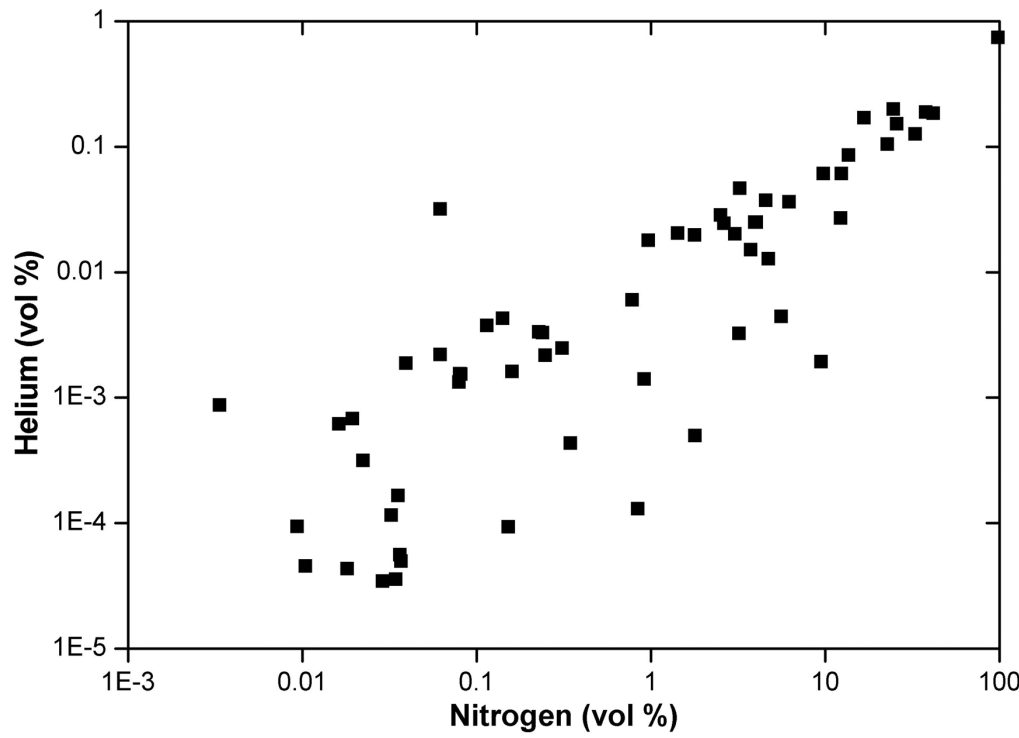

Fig. 7. Correlation between nitrogen and helium contents in gases of the western Eger Rift (data from Weinlich et al., 1998). 
a continuous enrichment by solubility fractionation (Weinlich et al., 1998). The assumption of an additional $\mathrm{N}_{2}$-source in case of the $\mathrm{N}_{2}$-richer gases is therefore not necessary. Compared to the gas release centres the nitrogen flux decreases in the springs in the marginal areas. An exception is the water inflow about $500 \mathrm{~m}$ below the surface with $100 \mathrm{l} / \mathrm{h} \mathrm{N}_{2}$ in the Schönbrunn fluorite mine, caused by pressure release in this mine.

A special case of these fractionations are springs with very low $\mathrm{Ca}-\mathrm{Mg}-\mathrm{HCO}_{3}$ contents and with isotopic composition of $\mathrm{CO}_{2}$ being still nearly unchanged due to lack of extensive $\mathrm{HCO}_{3}^{-}$ fractionation and where the $\mathrm{CO}_{2}$ contents are solely decreased by the solution of $\mathrm{CO}_{2}$. This can be explained by fractionation processes. However, in case of an interpretation of isotopically lighter $\mathrm{CO}_{2}$ in the gas distribution pattern of the western Eger Rift caused by mixing with lighter biogenic $\mathrm{CO}_{2}$ there should be no reason to elucidate why the mixing should not occur in springs with low Total Dissolved Solids (TDS) contents.

Regarding longer migration pathways as mentioned above it is considered that the gas migration occurs within different hydrological systems and therefore these fractionations can take place repeatedly during the migration. This results in a drastic drop of the $\mathrm{CO}_{2}$ contents and the $\delta^{13} \mathrm{C}$ values in the remaining gas phase.

Figure 5 demonstrates the isotopic composition of the $\mathrm{N}_{2}$-rich gases in the Fluorite mine of Schönbrunn (one of the most northern springs shown in fig. 1) with a $\delta^{13} \mathrm{C}$ value of $-17.4 \%$ which can be explained alone under the assumption that the $\mathrm{CO}_{2}-\mathrm{HCO}_{3}^{-}$system is equilibrated twice.

Certainly, an admixture of biogenic $\mathrm{CO}_{2}$ cannot be excluded but in this mine about $3.6 \mathrm{~m}^{3}$ of $\mathrm{CO}_{2}$ gas and $3664 \mathrm{~m}^{3}$ of dissolved $\mathrm{CO}_{2}$ per year were released. Facing the fact that the granite surface is located only about $650 \mathrm{~m}$ below both the thermal water and gas inflows (Kuschka and Hahn, 1996) this amount is hardly explainable with noticeable proportions of biogenic $\mathrm{CO}_{2}$. It is problematic to derive the nitrogen from crustal sources in terms of the $100 \mathrm{l} / \mathrm{h} \mathrm{N} \mathrm{N}_{2}$ in the free gas phase and about $450 \mathrm{l} / \mathrm{h}$ dissolved $\mathrm{N}_{2}$ (air-free over dissolved Ar; procedure in Weinlich et al., 1998) accompanied by $0.45 \mathrm{l} / \mathrm{h}$ He and $5.72 \mathrm{l} / \mathrm{h}$ dissolved $\mathrm{He}$ (in total $54 \mathrm{~m}^{3} / \mathrm{yr} \mathrm{He}$ ). It should be considered that due to the intrusion of Variscian granites the metamorphic rocks were exposed to far higher temperatures, as is the case today. Therefore, the $\mathrm{N}_{2}$ is probably also mantle derived, because the $\mathrm{N}_{2}$ gas release including metamorphic $\mathrm{CO}_{2}$ sourced from these crustal rocks took place during the Variscian intrusions. The nitrogen isotope composition with $\delta{ }^{15} \mathrm{~N} 0.7$ (Weinlich et al., 1999) exhibits a tendency to more positive values of a plume-like mantle (Marty and Dauphas, 2003) which occurs in Central Europe (Wilson and Downes, 1992).

Recalculating the $\mathrm{CO}_{2}$ and $\mathrm{N}_{2}$ in the gas phase together with the dissolved $\mathrm{N}_{2}$, and $\mathrm{CO}_{2}$ including the $\mathrm{HCO}_{3}^{-}$the whole fluid system contains about 90 vol\% $\mathrm{CO}_{2}$ (possible $\mathrm{CaCO}_{3}$ precipitations would additionally increase this $\mathrm{CO}_{2}$ content) and about $10 \mathrm{vol} \% \mathrm{~N}_{2}$ and thus this system is comparable with the Eger Rift gases.

\subsection{The gases of the French Massif Central}

The distribution pattern and the isotopic signature of -23 up to $-12 \%$ of the $\mathrm{N}_{2}$-rich spring gases of the French Massif Central could be explained in the same way. As in the western Eger Rift, the $\mathrm{CO}_{2}$-rich gases with $\delta^{13} \mathrm{C}$ values of -7 up to $-5 \%$ are linked with high gas fluxes in the concerned mineral springs. Figure 8 demonstrates this correlation between $\delta^{13} \mathrm{C}$ values and the gas composition. Batard et al. (1982) calculated initial isotope composition for some gases in this area with mass balances according to a single equilibration $\mathrm{CO}_{2}-\mathrm{HCO}_{3}^{-}$. The authors concluded a biogenic or mixed origin for the $\mathrm{CO}_{2}$ because the isotopic composition of the total carbon ranges between -16 and $-11 \%$. However, due to multiple equilibrations, it cannot be excluded a priori but only the $m_{\mathrm{HCO}_{3}} / m_{\text {total }}$ ratios near 0 should be used to avoid misinterpretations (the calculated $\delta^{13} \mathrm{C}$ value of $\mathrm{CO}_{2}$ for Schönbrunn assuming a single equilibration is also $-11 \%$ ).

For the gases of the French Massif Central, it can be assumed that the gas of Royat with a $\delta^{13} \mathrm{C}$ value of $-6.4 \%$ is unfractionated owing to its $m_{\mathrm{HCO}_{3}} / m_{\text {total }}$ ratio of 0.007 and displays the primary composition. Further, geothermometer calculations (Pauwels et al., 1997) indicate that 


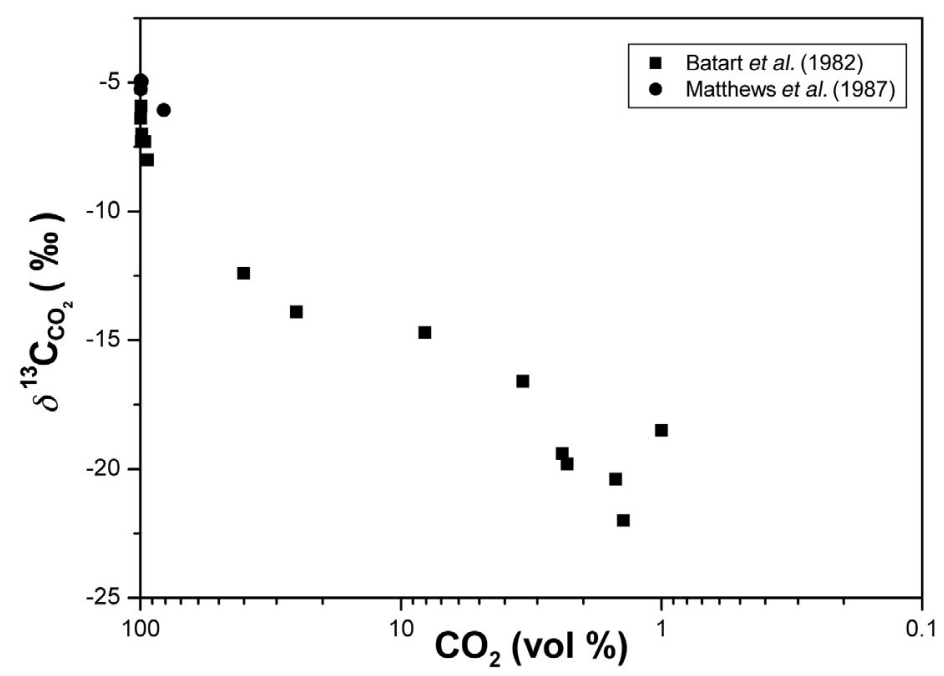

Fig. 8. Correlation of gas composition and isotopic composition of $\mathrm{CO}_{2}$ in gases of the Massif Central (data from Batard et al., 1982 and Matthews et al., 1987).

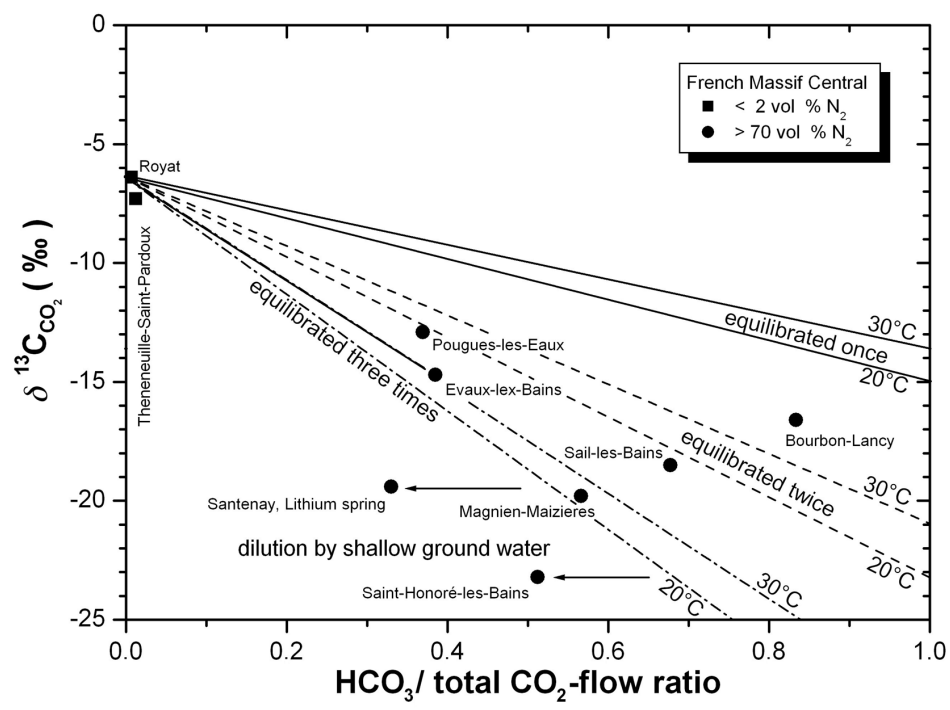

Fig. 9. Mass balance plot displays $\delta^{13} \mathrm{C}$ values versus ratio $\mathrm{HCO}_{3}^{-}$transport $\left(m \mathrm{HCO}_{3}\right)$ to total $\mathrm{CO}_{2}$ flux $\left(m_{0}\right)$ for gases of mineral springs in the French Massif Central (data from Batard et al., 1982).

these waters emerging in the Mont Dore area reach temperatures of about $100-130^{\circ} \mathrm{C}$ at depth and in Saint-Nectaire $\left(\delta^{13} \mathrm{C}\right.$ value $\mathrm{CO}_{2}$ $-7.0 \%$ ) temperatures of $160-175^{\circ} \mathrm{C}$ at depth respectively. According to Mook et al. (1974), the fractionation between $\mathrm{CO}_{2}$ and $\mathrm{HCO}_{3}{ }^{-}$at temperatures of around $120^{\circ} \mathrm{C}$ is zero. Based on the isotope composition of Royat it can be shown that the low values of -12 and $-23 \%$ o can be reached (fig. 9) under the assumption 
that the equilibration between $\mathrm{CO}_{2}$ and $\mathrm{HCO}_{3}^{-}$ takes place only twice and in two cases three times. Therefore, it is not absolutely necessary to assume biogenic contributions in the region as well as in the Eger Rift. Just two isotope values, which represent gases of Santenay and Saint Honoré, situated at the edge of the Morvan horst and which are associated with $\mathrm{Na}-$ $\mathrm{SO}_{4}$ waters are lighter than those lying in the field of gases equilibrated three times. However, an uncertainty of these mass balances lies within the possibility of influence of non-mineralised groundwaters and/or mineral waters of different type, which «dilute» the $\mathrm{HCO}_{3}^{-}$-rich mineral water in the respective springs.

In the Cézallier area, Négrel et al. (2000) demonstrate such mixtures of mineral waters with meteoric and different mineralised waters in line with the REE distribution and strontium isotope ratios. Pauwels et al. (1997) state similar processes in the Mont Dore region on the basis of the main element distribution in spring waters. This effect of «dilution» of these mineral waters can produce lower $m_{\mathrm{HCO} 3} / m_{\text {total }}$ ratios, present during equilibration in deeper regions as higher $m_{\mathrm{HCO}_{3}} / m_{\text {total }}$ ratios. Since the $\mathrm{CO}_{2}$ of these $\mathrm{N}_{2}$-rich gases is completely fixed as $\mathrm{HCO}_{3}^{-}$, it is no longer possible to form new $\mathrm{HCO}_{3}^{-}$in these waters. The $\delta^{13} \mathrm{C}$ values were altered by the formed $\mathrm{HCO}_{3}^{-}$and remained unchanged in less mineralised waters. This results in a shift of these gases in plot of the ratio of $\mathrm{HCO}_{3}^{-}$versus total $\mathrm{CO}_{2}$ flow (fig. 9) and acts as if a thrice equilibration took place. According to Schoeller and Schoeller (1979) the TDS contents and especially the $\mathrm{HCO}_{3}^{-}$contents decrease with increasing distances from the area of Vichy-Cantal-Devès.
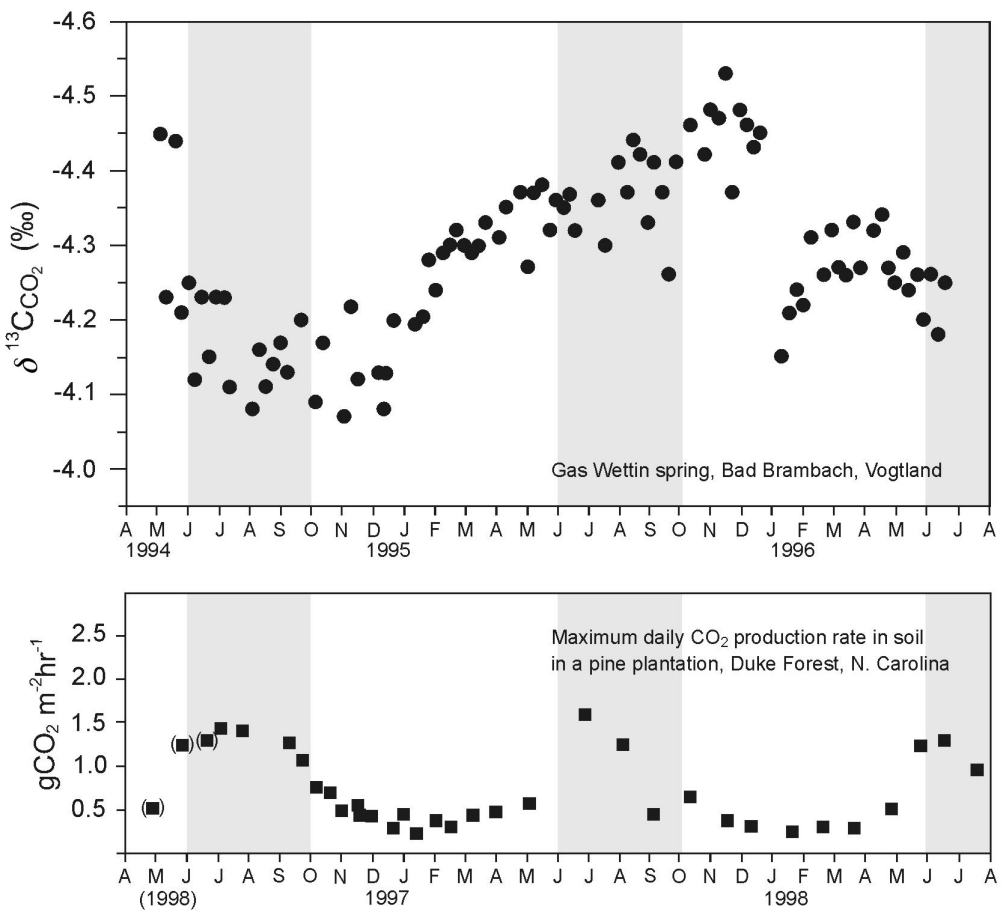

Fig. 10. Long-term observation of isotopic composition of the gas of the Eisen spring in Bad Brambach, Eger Rift (Weise et al., 2002) and typical annual changes in the $\mathrm{CO}_{2}$ production in soils (Andrews and Schlesinger, 2001). Growing seasons - light grew. 
As in the western Eger Rift, the $\mathrm{N}_{2}$-rich gases in the Massif Central are enriched in helium. The extreme enrichment of helium, whose contents are the highest in Europe, points rather to a complete fractionation than to a simple mixing with biogenic components. According to the gas flux measurement of Batard et al. (1982) $30 \mathrm{l} / \mathrm{h}$ of $\mathrm{N}_{2}$ are also released in the $\mathrm{CO}_{2}$ rich gases of Royat. On the other hand, $\mathrm{N}_{2}$ release in the case of $\mathrm{N}_{2}$-rich gases are $c a .2 .8 \mathrm{l} / \mathrm{h}$ in Bourbon-Lancy, $29.6 \mathrm{l} / \mathrm{h}$ in Evaux-les-Bains, $0.5 \mathrm{l} / \mathrm{h}$ in Sail-les-Bains and $1.7 \mathrm{l} / \mathrm{h} \mathrm{N}_{2}$ in the Lithium spring in Santenay. Thus only the gas composition is fractionated and it is not necessary to assume additional $\mathrm{N}_{2}$ sources.

An additional argument contradicting the influence of mixing processes is that outside these areas with magmatic $\mathrm{CO}_{2}$ there are no springs with biogenic/organic $\mathrm{CO}_{2}$ in the gas phase. The production rates of biogenic $\mathrm{CO}_{2}$ in soils (Andrews and Schlesinger, 2001) are too small to nourish a free gas phase. A long-term measurement of isotope composition of $\mathrm{CO}_{2}$ in the gas phase of the Wettin spring in Bad Brambach (Weise et al., 2001) compared with the biogenic $\mathrm{CO}_{2}$ production rates (Andrews and Schlesinger, 2001) demonstrate that there is no influence (fig. 10).

It is also problematic to derive biogenic/organic $\mathrm{CO}_{2}$ from sedimentary rocks, especially in areas of metamorphic rocks, since these waters and gases circulate within fault systems. There, either a far-reaching $\mathrm{CO}_{2}$ exchange between the gases migrating along fault pathways and the surrounding country rocks is impeded or the ascending magmatic $\mathrm{CO}_{2}$ saturates the groundwater with $\mathrm{CO}_{2}$ gas, as it is the case in the Cheb Basin. The $\mathrm{CO}_{2}$ concentration gradient in the close vicinity of the faults prevents the admixture of $\mathrm{CO}_{2}$ from other sources like for example the biogenic/organic $\mathrm{CO}_{2}$.

\section{Conclusions}

As demonstrated, it is possible to elucidate low $\delta^{13} \mathrm{C}$ values with gas fractionation, i.e. by isotope fractionation with formed $\mathrm{HCO}_{3}^{-}$and not necessarily and exclusively by mixing with biogenic or organic $\mathrm{CO}_{2}$. However, without complete mass balances it is not possible to dis- criminate between either or give reasons to prefer one of the interpretations. In some cases, it will not be possible to educe the «last proof» for the interpretation. Therefore, it should always be considered that even enhanced $\mathrm{CO}_{2}$ contents in the soil air encountered in the vicinity of fractured rocks can also represent completely fractionated magmatic $\mathrm{CO}_{2}$.

However, if we have to assume that the isotopic composition and contents of $\mathrm{CO}_{2}$ in the gas phase can be alternated by fractionation processes, an influence on the $\mathrm{C}^{\beta} \mathrm{He}$ ratios should also be assumed. Marty et al . (1989) described abating $\mathrm{C}^{3} \mathrm{He}$ linked with reduced $\mathrm{CO}_{2}$ contents.

\section{Acknowledgements}

The author would like to express his gratitude to Fausto Grassa, Istituto Nazionale di Geofisica e Vulcanologia - Sezione di Palermo, for providing constructive comments to the review. The support of H.W. Hubberten, A. Wegner Inst. f. Polar Marin Res., Potsdam in his permission to use his unpublished data is greatly appreciated. K. Puitz, Staatsbad Bad Bertrich is thanked for supplying gas samples. For constructive discussions I would like to thank Jolanta Kus and Franz May, BGR Hannover.

\section{REFERENCES}

Andrews, J.A. and W.H. Schlesinger (2001): Soil $\mathrm{CO}_{2}$ dynamics, acidification, and chemical weathering in a temperate forest with experimental $\mathrm{CO}_{2}$ enrichment, Global Biochem. Cycles, 15, 149-162.

Autran, A., J-P. Breton and J.C. Chiron (coordinator) (1980): Carta tectonquie de la France 1:1000 000, Mem. BRGM 110, pp. 52.

Batard, F., J.C. Baubron, B. Bosch, A. Marcé and J.J. RISLER (1982): Isotopic identification of gases of a deep origin in French thermomineral waters, J. Hydrol., 56, 1-21.

Baubron, J-P., B. Bosch, P. Desgranges, M. Leleu, J.J. RISLER and C. SARCIA (1979): Recherches géocimiques sur les eaux thermals de la bordure oust de la Limagne, Bull. Minéral, 102, 676-683.

BEYER, F. (1995): Isotopenhydrogeologie der Aachener Thermalquellen, Geol. Inst. Univ. Köln, Sonderveröffentlichungen 105, p. 148.

CAPAsso, G., R. Favara and S. Inguaggiato (1997): Chem- 
ical features and isotopic composition of gaseous manifestations on Vulcan Island, Aeolian Islands, Italy: an interpretative model of fluid circulation, Geochim. Cosmochim. Acta, 61, 3425-3440.

Chiodini, G., F. Frondini, D.M. Kerrick, J. Rogie, F. ParEllo, L. PeruZzi and A.R. ZanZari (1999): Quantification of deep $\mathrm{CO}_{2}$ fluxes from Central Italy. Examples of carbon balance for regional aquifers and of soil diffuse degassing, Chem. Geol., 159, 205-222.

D’Alesandro, W., S. De Gregorio, G. Dongarrà, S. Gurrieri, F. PARello and B. PARISI (1997): Chemical and isotopic characterization of the gases of Mount Etna (Italy), J. Volcanol. Geotherm. Res., 78, 65-76.

GRIESSHABER, E., R.K. O'NiONS and E.R. OXBURGH (1992): Helium and carbon isotope systematics in crustal fluids from the Eifel, the Rhine Graben and Black Forest (FRG), Chem. Geol., 99, 213-135.

KolÁŘová, M. and V. Myslil (1979): Minerální vody Západočeského kraje, UUG (Geol. Surv.) Praha, p. 286.

KuschKA, E. and W. HAHN (1996): Flußspatlagerstätten des Südwestvogtlandes: Schönbrunn, Bösenbrunn, Wiedersberg, Bergbau in Sachsen, Bd. 2 (Landesamt Umwelt u. Geol, Sächs. Oberbergamt), p. 281.

MARTY, B. and N. DAUPHAS (2003): The nitrogen record of crust-mantle interaction and mantle convection from Archean to present, Earth Planet. Sci. Lett., 204, 397-410.

Marty, B., A. JAMBON and Y. SANO (1989): Helium isotopes and $\mathrm{CO}_{2}$ in volcanic gases of Japan, Chem. Geol., 76, 25-40.

Matthews A., C. Fouillac, R. Hill, R.K. O’Nions and E.R. OXBURGH (1987): Mantle-derived volatiles in continental crust: the Massif Central of France, Earth Planet. Sci. Lett., 85, 117-128.

MaY, F. (2002): Quantifizierung des $\mathrm{CO}_{2}$-Flusses zur Abbildung magmatischer Prozesse im Untergrund der Westeifel (Shaker Verlag), p. 170.

Mook, W.G., J.C. Bommerson and W.H. STAVERMAN (1974): Carbon isotope fractionation between dissolved bicarbonate and gaseous Carbon dioxide, Earth Planet. Sci. Lett., 22, 169-176.

Moureu, CH. (1923): Les gaz rares des gaz naturels, J. Chem. Soc., 123, 1905-1947.

Moureu, CH. and A. LePAPE (1912): Sur quelques mélanges gazeux naturels particulièrement riches en hélium. Gisements d'hélium, C.R. Acad. Sci. Paris, 155, 197-200.

Négrel, Ph., C. Guerrot, A. Cocherie, M. Azaroual, M. BRACH and CH. FouillaC (2000): Rare earth elements, neodymium and strotium isotopic systemtics in mineral waters: evidence from the Massif Central, France, Appl. Geochem., 15, 1345-1367.

Pauwels, H. and C. Foulliac (1997): The isotopic and chemical composition of $\mathrm{CO}_{2}$-rich thermal waters in the Mont-Dore region (Massif-Central, France), Applied Geochmistry, 12, 411-427.

Risler, J.J., G. Castany, J. Margat, L. Monition and D.B. NinARD (1973): Carte des eaux minérales et thermales de la France 1:1 000 000, Mem. BRGM.

Schoeller, H. and M. Schoeller (1979): Une étude des eaux thermominérales du Massif Central Français, Bull. BRGM, Sec. III, 2, 121-156.

Weinlich, F.H. (1989): Geochemie und Genese des Stickstoffs in den vogtländisch-erzgebirgischen Quellgasen, Z. Angew. Geol., 35, 129-135.

Weinlich, F.H., J. TESAR̆, S.M. Weise, K. BRÄUER and H. KÄMPF (1998): Gas flux distribution in mineral springs and tectonical structure in the western Eger Rift, $J$. Czech Geol. Soc., 43, 91-110.

Weinlich, F.H., K. Bräuer, H. Kämpf, G. Strauch, J. TESAR̆ and S.M. WEISE (1999): An active subcontinental mantle volatile system in the western Eger Rift, Central Europe: gas flux, isotopic ( $\mathrm{He}, \mathrm{C}$ and $\mathrm{N}$ ) and compositional fingerprints, Geochim. Cosmochim. Acta, 63, 3653-3671.

Weinlich, F.H., K. Bräuer, H. Kämpf, G. Strauch, J. TESAř and S.M. WeIsE (2003): Gas flux and tectonic structure in the western Eger Rift, Karlovy Vary Oberpfalz and Oberfranken, Bavaria, GeoLines, Prague, 15, 171-177.

Weise, S.M., K. BräUer, H. KÄMPf, G. Strauch and U. KосH (2001): Transport of mantle volatiles through the crust traced by seismically released fluids: a natural experiment in the earthquake swarm area Vogtland/NW Bohemia, Central Europe, Tectonophysics, 336, $137-150$.

WENDT, I. (1968): Fractionation of carbon isotopes and its temperature dependence in the system $\mathrm{CO}_{2}-\mathrm{Gas}-\mathrm{CO}_{2}$ in solution and $\mathrm{CO}_{3}-\mathrm{CO}_{2}$ in solution, Earth Planet. Sci. Lett., 4, 64-68.

WiLson, M. and H. Downes (1992): Mafic alkaline magmatism associated with the European Cenozoic rift system, Tectonophysics, 208, 172-182.

Zhang, J., P.D. QuAY and D.O. WILbuR (1995): Carbon isotope fractionation during gas-water exchange and dissolution of $\mathrm{CO}_{2}$, Geochim. Cosmochim. Acta, 59, 107-114. 